БЕЙГУЛ С.В.

\title{
ФОРМИ УПРАВЛІНСЬКИХ РІШЕНЬ У ДІЯЛЬНОСТІ ТЕРИТОРІАЛЬНИХ ОРГАНІВ НАЦІОНАЛЬНОЇ ПОЛІЦІЇ УКРАЇНИ
}

У статті відзначено брак системних напрацювань щодо визначення форм управлінських рішень як загалом, так і у діяльності територіальних органів Національної поліції України зокрема. Проаналізовано твердження науковців, на основі чого здійснено власний висновок щодо особливостей форм управлінських рішень у діяльності територіальних органів Національної поліції України. Зокрема, автором запропоновано виділяти матеріально зафіксовані та матеріально не зафіксовані управлінські рішення. Надалі з'ясовано сутність та окремі особливості наведених форм управлінських рішень та вимог до них. Відзначено особливості критеріїв вибору форми управлінського рішення в діяльності територіальних органів Національної поліції України.

Зроблено висновок, що форма управлінських рішень у діяльності територіальних органів Національної поліції України є важливим елементом у структурі налагодження ефективної управлінської діяльності. Сьогодні нагальною проблемою $є$ розробка та затвердження критеріїв оперативних ситуацій, обставин, проблем, які потребують вирішення та завдань, що необхідно виконати під час реалізації своїх повноважень, за якими працівники територіальних органів Національної поліції України матимуть змогу чітко визначати форму, у якій необхідно прийняти управлінське рішення, та обрати його вид у межах такої форми. На наш погляд, такі критерії повинні містити оцінку: (1) питання, проблеми, завдання, які необхідно вирішити чи виконати за допомогою управлінського рішення: чи це загальні, стратегічні питання, або ж питання поточної діяльності, конкретна оперативна ситуація тощо; (2) характер припису, який зумовлений актом суб'єкта управління: нормативний, індивідуально-правовий; (3) сферу питання чи проблеми, що потребує вирішення: щодо вирішення питань матеріально-технічного, кадрового забезпечення, організаційної діяльності, реалізація повноважень щодо захисту суспільних цінностей, дозвільного характеру тощо; (4) особливості контакту з об'єктом управління та виконавцем рішення: безпосередній контакт, опосередковане доведення до відома; (5) часу, необхідного для розробки та прийняття управлінського рішення.

Ключові слова: форми управлінських рішень, Національна полічія, документ, наказ, рапорт, усний акт, конклюдентна дія.

The article points to a lack of systematic experience in determining the forms of administrative decisions both in general and in the activities of the territorial bodies of the National Police of Ukraine. Scientists' statements are analyzed, on the basis of which their own conclusion is drawn about the peculiarities of forms of administrative decisions in the activity of territorial bodies of the National Police of Ukraine. In particular, the author proposes to allocate materially fixed and materially fixed management decisions. The following describes the nature and specific features of these forms of management decisions and requirements. The peculiarities of the criteria for choosing the form of administrative decision in the activity of territorial bodies of the National Police of Ukraine are noted. It is concluded that the form of administrative decisions in the activities of territorial bodies of the National Police of Ukraine is an important element in the structure of establishing effective management activities. Today, the urgent problem is the development and approval of criteria for operational situations, circumstances, problems that need to be solved and tasks to be performed in

(С БЕЙГУЛ С.В. - здобувач (Науково-дослідний інститут публічного права) 
the exercise of their powers, whereby employees of the territorial bodies of the National Police of Ukraine will be able to clearly define the form in which to make a management decision. and choose its appearance within this form. In our view, the following criteria should include an assessment of: (1) issues, problems, tasks that need to be addressed or accomplished through a management decision: whether these are general, strategic, or ongoing activities, a specific operational situation, etc.; (2) the nature of the order, which is determined by the act of the subject of management: normative, individuallegal; (3) the scope of the issue or problem that needs to be resolved: to resolve the issues of logistical, personnel, organizational activity, the exercise of authority to protect public values, permits, etc.; (4) specifics of contact with the management entity and the executor of the decision: direct contact, indirect communication; (5) the time required to develop and make management decisions.

Key words: forms of administrative decisions, National police, document, order, report, oral act, conclusive action.

Вступ. Для здійснення належного організаційно-розпорядчого, спрямовуючого, регулюючого та іншого впливу на об'єкт управління управлінське рішення повинне у необхідний спосіб отримати своє зовнішнє вираження та закріплення. Адже не підлягають будь-якому усвідомленню та виконанню міркування, погляди чи прагнення суб'єкта управління, які ним не транслюються об’єкту та не виявляються у відповідній формі. Сьогодні чіткого визначення поняття «форма управлінського рішення» у теорії адміністративного права не вироблено, не проведено класифікації таких форм та не розглянуто і не систематизовано критерії, за якими доцільно обирати відповідну форму управлінського рішення. Що стосується форми управлінських рішень у діяльності територіальних органів Національної поліції України, то різноплановість діяльності органів поліції та специфіка їхньої компетенції призводить до різноманіття форм управлінських рішень, кореляції таких рішень відповідно до особливостей об'єкта управління, динамічності формування окремих із таких рішень. Таким чином, теоретичне та практичне розуміння поняття «форма управлінського рішення у діяльності територіальних органів Національної поліції України», систематизація наведених форм є необхідною умовою проведення будь-яких подальших досліджень, а також і методологічним інструментарієм для повсякденної діяльності з реалізації функцій та повноважень територіальними органами Національної поліції України.

Аналіз останніх досліджень і публікацій. Серед науковців, які присвячували свої напрацювання розкриттю особливостей форм управлінських рішень, слід виділити Ю.В. Александрова, О.М. Бандурку, М.Ю. Віхляєва, О.П. Герасімова, С.В. Ківалова, Б.П. Курашвілі, Ю.О. Куца, В.М. Мартиненка, Н.П. Матюхіну та інших.

Виділення не вирішених раніше проблем. Проте доцільно зауважити, що зазначені вище вчені розробляли загальнотеоретичні питання обраної проблематики, що зумовлює необхідність та нагальність проведення спеціальних наукових досліджень питання форм управлінських рішень у діяльності територіальних органів Національної поліції України.

Постановка завдання. Метою статті $є$ визначення форм управлінських рішень у діяльності територіальних органів Національної поліції України та з'ясування окремих особливостей їхнього вибору та розробки.

Результати дослідження. Переходячи до безпосереднього розкриття зазначеного питання, відзначаємо недостатність теоретичної узгодженості понятійно-категоріального апарату обраної проблематики. Адже у доктрині адміністративного права бракує вчення про форми управлінських рішень та чіткого визначення зазначеного терміну. Науковці розглядають форми правозастосовчих актів органів державної влади, а також окремі праці збагачують термінологічний апарат адміністративного права розумінням та класифікацією форм правових актів органів державної влади. Наведений стан наукових розробок потребує проведення якісної наукової дискусії та уніфікації відповідних термінів та категорій. Отже, розглянемо запропоновані вченими погляди на визначення зазначених вище понять.

На думку В.В. Мухіна, який розглянув позицію І.Я. Дюрягіна [1, с. 247], правозастосовні акти можуть мати документальну, усну форму або форму дії. Відмінності форм зумовлюються різноманітністю способів вираження і закріплення волі органів держави і посадових осіб, що міститься в актах застосування норм права. Також В.В. Мухін врахував думку А. Коренєва [2, с. 172], який класифікує акти застосування права дещо по-іншому, виокремлюючи словесні та конклюдентні акти. Словесні своєю чергою він поділяє на письмові та усні. Аналіз наведеного 
підходу дає змогу дійти висновку про те, що правовий акт може мати форму документа (письмового чи електронного), усну форму чи форму дії. Обрання тієї чи іншої форми зумовлено характером суспільних відносин, що регулюються, обставинами, за яких правовий акт приймається, тощо. Зміст правового акта у цьому разі залишається незмінним, змінюється лише форма його зовнішнього вираження [3, с. 15$]$.

Схожу позицію висловлює також і О.Ю. Салманова, яка досліджує правові акти в управлінській діяльності Національної поліції України. Вона зауважує, що правові акти Нацполіції не завжди виражаються в документарній формі, зважаючи на різноманіття форм вираження таких актів, відповідно до вимог чинного законодавства. Зокрема, правові акти в управлінській діяльності НПУ можуть викладатись у таких трьох формах: (1) письмова форма.; (2) усна форма; (3) конклюдентна форма. Правовий акт поліції в формі конклюдентних дій «видається» тоді, коли уповноважена особа Нацполіції може здійснювати свою управлінську діяльність лише за рахунок передбачених чинним законодавством жестів та здійснення певних дій. Показовим прикладом цього випадку $\epsilon$ патрульна діяльність поліції, в якій правові акти у формі конклюдентних дій «видаються», головним чином, у разі: регулювання дорожнього руху; «вказівки» водіям транспортних засобів дати дорогу і забезпечити безперешкодний проїзд поліцейського автомобіля (і супроводжуваних ним транспортних засобів), яку вони оголошують таким водіям на проїзній частині за допомогою спеціальних проблискових маячків та/або спеціальних звукових сигналів, тощо [4, с. 54-55].

Аналізуючи вищенаведене, зауважуємо, що звичайно поняття «управлінські рішення» та «правозастосовні акти» не є тотожними за змістом, проте теоретичні погляди щодо форм таких актів можуть бути застосовані і під час розгляду форм управлінських рішень. Слід погодитися з позицією як В.В. Мухіна, так і О.С.Салманової, які розглядають декілька форм актів та не ототожнюють правовий акт, правозастосовний акт (в нашому випадку за аналогією - управлінське рішення в діяльності територіальних органів Національної поліції України) лише 3 його документальним вираженням (письмовим закріпленням).

У процесі здійснення управлінської діяльності територіальними органами Національної поліції України виникають різні оперативні та поточні ситуації, які потребують негайного реагування та прийняття миттєвих управлінських рішень та, відповідно, невідкладного їх доведення до відома об'єкта управління (особи, групи осіб тощо). Також існують ситуації, коли на розробку та прийняття управлінського рішення витрачаються місяці робочого часу (наприклад, розробка планів діяльності, стратегічних завдань органу та визначення виконавців тощо). У всіх окреслених випадках управлінські рішення є виявом владно-управлінського впливу на об'єкт управління, результатом реалізації наданих законодавством повноважень щодо здійснення державного управління у відповідній сфері. Тобто у обох випадках за своєю сутністю і природою такі акти $є$ управлінськими рішеннями, проте окремі обставини зумовлюють їхню відповідну форму. Водночас слід зазначити, що законодавством не закріплено необмеженої дискреції територіальних органів Національної поліції щодо вибору форм управлінських рішень та їх зовнішнього виразу. Кожна форма управлінського рішення повинна відповідати вимогам чинного нормативно-правового регулювання, тому форми управлінських рішень у діяльності територіальних органів Національної поліції визначені та обмежені чинним законодавством.

Щодо класифікації видів форм управлінських рішень, то обгрунтованою видається класифікація форм актів на усні, письмові та конклюдентні (форма дії). Проте, на нашу думку, доцільно їі дещо удосконалити у контексті проведення спеціального дослідження саме форм управлінських рішень у діяльності територіальних органів Національної поліції України. Таким чином, пропонуємо розглядати такі форми управлінських рішень в діяльності територіальних органів Національної поліції України: (1) матеріально зафіксовані та (2) матеріально не зафіксовані.

До першої форми - матеріально зафіксованих управлінських рішень в діяльності територіальних органів Національної поліції України, слід віднести вольові акти суб'єкта прийняття управлінського рішення організаційно-розпорядчого характеру, які отримали своє чітке вираження на матеріальних носіях інформації, можуть бути фізично збережені, оцінені, відтворені (тощо) необмежену кількість разів, характеризуються наявністю чітких реквізитів та зазвичай являють собою відповідний документ управлінської діяльності.

Серед матеріально зафіксованих управлінських рішень у діяльності територіальних органів Національної поліції України можна виокремити паперові документи, електронні документи, документи, що зафіксовані на інших матеріальних носіях інформації. Основною ознакою $є$ їхня матеріальна фіксованість, наявність визначених законодавством реквізитів та можливість повторного відтворення та оцінки. Серед них можна виділити організаційно-розпорядчі (ті, 
що регулюють внутрішньо організаційну діяльність територіальних органів Національної поліції України), а також правозастосовні - ті, які спрямовані на здійснення управлінського впливу на зовнішні правовідносини щодо охорони правопорядку, захисту прав і свобод.

Досить грунтовно питання матеріально зафіксованих управлінських рішень у діяльності територіальних органів Національної поліції України розкрито В.В. Сокуренком. Автор зазначає, що управлінські рішення можуть оформлюватись у різній формі, а саме: наказом, вказівкою, інструкцією, протоколом, висновками, листами, доповідними записками, довідками, рапортами, приписами тощо, але всі ці документи повинні відповідати обов'язковим вимогам. Кожен офіційний документ повинен мати назву виду документа, заголовок до тексту, дані про адресата, посилання на індекс і дату вхідного документа, якщо вихідний документ $\epsilon$ реагуванням на нього, дату відправки, назву установи, що підготувала документ, прізвище керівника чи працівника-виконавця тощо. Залежно від змісту і призначення документа вказуються гриф обмеження доступу до документа, терміновість виконання, гриф погодження, гриф затвердження, код форми документа за класифікатором управлінської діяльності (КУД). Адміністративно-процесуальні, кримінально-процесуальні, оперативно-розшукові документи повинні оформлюватись відповідно до адміністративно-процесуального, кримінально-процесуального законодавства та нормативних актів МВС України та Національної поліції України [5, с. 179-182]. Щодо інших загальних вимог до управлінських рішень, то К.Я. Прохоренко досліджує позицію В.В. Конопльова, який до вимог, які висуваються до управлінських рішень, відносить такі: чіткість, зрозумілість для виконавців, конкретність та підконтрольність [6, с. 83]. Також автор аналізує думку В.М. Плішкіна [7, с. 166], який зазначає, що для того щоб прийняте управлінське рішення керівника було найбільш ефективним, воно повинно відповідати ряду вимог: бути науково обгрунтованим, законним, актуальним, реальним, конкретним, несуперечливим, своєчасним, інформативним [8].

Оформлення матеріально зафіксованих управлінських рішень в діяльності територіальних органів Національної поліції України тісно взаємопов'язане з процесом документування управлінської діяльності, документообігом у зазначених органах, що регулюються відповідно до Інструкції з діловодства в системі Національної поліції, що затверджена Наказом Національної поліції України від 20.05.2016 № 414 [9]. Відповідно до Інструкції організаційно-розпорядча документація - це уніфікована підсистема управлінської документації, що забезпечує організацію процесів управління та управлінської праці; управлінський документ - це службовий документ, спрямований на виконання установою функцій, що забезпечують їі діяльність. До управлінських документів належать організаційно-розпорядчі, первинно-облікові, банківські, фінансові, звітно-статистичні, планові, ресурсні тощо.

Відповідно до ДСТУ 4163-2003 «Уніфікована система організаційно-розпорядчої документації. Вимоги до оформлювання документів», готуючи та оформлюючи документи, використовують такі реквізити: 01 - зображення Державного Герба України, герба Автономної Республіки Крим; 02 - зображення емблеми організації або товарного знака (знака обслуговування); 03 - зображення нагород; 04 - код організації; 05 - код форми документа; 06 - назва організації вищого рівня; 07 - назва організації; 08 - назва структурного підрозділу організації; 09 - довідкові дані про організацію; 10 - назва виду документа; 11 - дата документа; 12 - реєстраційний індекс документа; 13 - посилання на реєстраційний індекс і дату документа, на який дають відповідь; 14 - місце складення або видання документа; 15 - гриф обмеження доступу до документа; 16 - адресат та інші відповідні реквізити [10].

Підсумовуючи наведене вище, зауважуємо, що матеріально зафіксовані управлінські рішення характеризуються наступними ознаками: (1) це форми управлінських рішень, особливості створення яких визначаються відповідно до положень чинного законодавства: Законів України «Про державну таємницю», «Про інформацію», «Про Національний архівний фонд та архівні установи», іншими законами, Кримінальним процесуальним кодексом України, Кодексом України про адміністративні правопорушення, указами Президента, постановами Кабінету Міністрів, іншими підзаконним нормативно-правовими актами, державними стандартами; (2) вимоги до реквізитів, структури таких рішень є уніфікованими, імперативно визначеними відповідно до положень законодавства; (3) зміст управлінського рішення в діяльності територіальних органів Національної поліції України у наведеній формі виражається за допомогою орфографічних засобів, правильного письмового викладення суті акту суб'єкта прийняття управлінського рішення; (4) матеріально зафіксовані управлінські рішення складають основу документообігу в діяльності територіальних органів Національної поліції України. Організацію належного до- 
кументування управлінської діяльності, оформлення, тиражування, збереження та інші правові дії з матеріально зафіксованими формами управлінських рішень здійснює та організовує спеціально утворений Департамент документального забезпечення або відповідальна посадова особа у територіальному органі Національної поліції, а відповідальність за наведене несе керівник відповідного структурного підрозділу; (5) в межах матеріально зафіксованої форми управлінських рішень у діяльності територіальних органів Національної поліції України можна виділяти такі їх види: накази, директиви, плани, листи, інструкції, рапорти, положення, постанови (по справі про адміністративне правопорушення, наприклад), протоколи, висновки, рішення тощо. Для забезпечення оперативності документування управлінської діяльності можуть затверджуватися бланки відповідних видів документів. Обрання окремого виду матеріально зафіксованої форми управлінських рішень залежить від компетенції суб'єкта прийняття управлінського рішення, особливостей об'єкта управління, змісту питань, що вирішуються рішенням та сутності завдань, які закріплюються управлінським рішенням; (6) матеріально зафіксована форма управлінських рішень - це, за своєю правовою природою - документ, що характеризується наявністю конкретних реквізитів та змісту. Серед документів також доцільно виділяти такі види, як паперові та електронні (інформація в якому зафіксована у вигляді електронних даних, уключаючи обов'язкові реквізити документа).

До другої форми - матеріально незафіксованих управлінських рішень в діяльності територіальних органів Національної поліції України, відносимо визначений відповідно до вимог чинного законодавства зовнішньо не задокументований вияв владно-розпорядчої волі суб'єкта прийняття управлінського рішення, який зумовлений особливостями об'єкта управління та обставинами прийняття управлінського рішення, за якого дотримується вимога його оперативного прийняття, одночасного доведення змісту до об'єкта управління та необхідність невідкладного виконання, а також однозначність розуміння такого управлінського рішення. Серед таких управлінських рішень можна зазначити усні акти та конклюдентні дії (заходи), а також комбіновані управлінські рішення (поєднання усної форми та вчинення поліцейських заходів).

Висновки. Підсумовуючи наведене вище, зауважуємо, що форма управлінських рішень у діяльності територіальних органів Національної поліції України є важливим елементом у структурі налагодження ефективної управлінської діяльності. Сьогодні нагальною проблемою $\epsilon$ розробка та затвердження критеріїв оперативних ситуацій, обставин, проблем, які потребують вирішення, та завдань, що необхідно виконати під час реалізації своїх повноважень, за якими працівники територіальних органів Національної поліції України матимуть змогу чітко визначати форму, у якій необхідно прийняти управлінське рішення та обрати його вид у межах такої форми. На наш погляд, такі критерії повинні містити оцінку: (1) питання, проблеми, завдання, які необхідно вирішити чи виконати за допомогою управлінського рішення: чи це загальні, стратегічні питання, або ж питання поточної діяльності, конкретна оперативна ситуація тощо; (2) характер припису, який зумовлений актом суб'єкта управління: нормативний, індивідуально-правовий; (3) сферу питання чи проблеми, що потребує вирішення: щодо вирішення питань матеріально-технічного, кадрового забезпечення, організаційної діяльності, реалізація повноважень щодо захисту суспільних цінностей, дозвільного характеру тощо; (4) особливості контакту 3 об'єктом управління та виконавцем рішення: безпосередній контакт, опосередковане доведення до відома; (5) часу, необхідного для розробки та прийняття управлінського рішення.

\section{Список використаних джерел:}

1. Дюрягин И.Я. Применение норм светского права. Теоретические вопросы. Свердловск : Сред.-Урал. КН. Изд-во, 1973. 247 с. 1999. $280 \mathrm{c}$.

2. Коренев А.П. Административное право России : учебник : в 3 ч. Ч. 1. Москва : Щит-М.

3. Мухін В.В. Правозастосовний акт як форма індивідуального правового регулювання. Науковий вісник Міжнародного гуманітарного університету. Серія: Юриспруденція. 2016. Вип. 23. С. 14-16.

4. Салманова О.Ю. Правові акти в управлінській діяльності Національної поліції України : монографія. Харків : Панов. 2016. 460 с.

5. Управління органами Національної поліції України : підручник / за заг. ред. д-ра юрид. наук., доц. В.В. Сокуренка ; [О.М. Бандурка, О.І. Безпалова, О.В. Джафарова та ін. ; передм. В.В. Сокуренка] ; МВС України. Харків. нац. ун-т внутр. Справ. Харків : Стильна типографія. 2017. $580 \mathrm{c}$. 
6. Конопльов В.В. Теоретичні та практичні аспекти інформаційного забезпечення розробки та прийняття управлінських рішень у сучасній адміністративній діяльності органів внутрішніх справ. Право і Безпека. 2013. № 2. С. 82-86.

7. Плішкін В.М. Теорія управління органами внутрішніх справ: підручник ; за ред. Ю.Ф. Кравченка. Київ : НАВСУ. 1999. 702 с.

8. Прохоренко К.Я. Вимоги до управлінських рішень в діяльності органів Національної поліції. URL: http://109.237.87.242/bitstream/123456789/3267/1/\%D0\%9F\%D1\%80\%D0\%BE\%D1 $\% 85 \% \mathrm{D} 0 \% \mathrm{BE} \% \mathrm{D} 1 \% 80 \% \mathrm{D} 0 \% \mathrm{~B} 5 \% \mathrm{D} 0 \% \mathrm{BD} \% \mathrm{D} 0 \% \mathrm{BA} \% \mathrm{D} 0 \% \mathrm{BE} \% 20 \% \mathrm{D} 0 \% 9 \mathrm{~A} . \% \mathrm{D} 0 \% \mathrm{AF}$. .pdf.

9. Про затвердження Інструкції з діловодства в системі Національної поліції : Наказ Національної поліції України від 20.05.2016 №414. URL : http://tranzit.ltd.ua/nakaz/

10. Уніфікована система організаційно-розпорядчої документації. Вимоги до оформлювання документів ДСТУ 4163-2003 : Наказ Держспоживстандарту від 07.04.2003 p. № 55 . URL: https://zakon.rada.gov.ua/rada/show/v0055609-03.

УДК 342.9

DOI https://doi.org/10.32844/2618-1258.2019.6.23

БІЛОУС О.В.

\section{ПРИЙОМИ ТА ПРАВИЛА КОНТЕКСТУАЛЬНОГО ТЛУМАЧЕННЯ ПОНЯТЬ ТА КАТЕГОРІЙ АДМІНІСТРАТИВНОГО СУДОЧИНСТВА}

У статті на підставі узагальненого аналізу наукових, публіцистичних та нормативних джерел визначено прийоми та правила контекстуального тлумачення понять та категорій адміністративного судочинства. Відзначено, що контекстуальне тлумачення понять і категорій адміністративного судочинства - це сукупність прийомів і правил, в основі застосування яких знаходиться контекстуальний аналіз, за допомогою якого встановлюється зміст відповідного поняття або категорії адміністративного процесу з огляду на соціокультурні, правозастосовні та/або ситуаційні контексти їх значення.

Зауважено, що контекстуальне тлумачення розглядається у нерозривному зв'язку із філологічним тлумаченням, оскільки контекстуальний спосіб інтерпретації $€$ своєрідним підвидом філологічного тлумачення, а його основний метод - контекстуальний аналіз - $є$ складовою частиною лінгвістичного аналізу.

На підставі зазначеного сформульовано основні правила та прийоми контекстуального тлумачення понять і категорій адміністративного судочинства, зокрема: прийом гармонійного читання - зміст понять або категорій, що стосуються одного інституту адміністративного процесу або процесу загалом, повинен тлумачитися таким чином, щоб зробити їх сумісними, а не такими, що суперечать один одному; пов'язані слова мають значення одне для одного; поняттям надається те значення, яке 3 ними пов'язується в певному колі осіб; назви та заголовки є допустимими показниками значення відповідного поняття, сформульованого у КАС; якщо в законодавчому акті не визначено тим чи іншим способом значення юридичних термінів, їм слід надавати те значення, в якому вони вживаються в актах тлумачення або в юридичній доктрині, тощо; застосування прийомів ситуаційного контекстуального аналізу до тлумачення оціночних понять.

Ключові слова: адміністративне судочинство, аналіз, поняття, категорії, філологічне тлумачення, контекст.

(с) БІЛОУС О.В. - кандидат юридичних наук, суддя (Верховний Суд) 